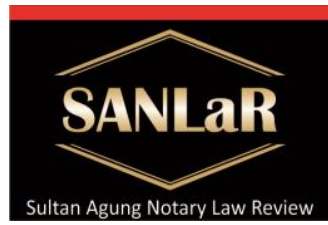

Volume 3 No. 1, March 2021

\title{
The Legal Aspect of Fingering Mother Cap in the Making of Land \& Buying Deals
}

\author{
Anik Setiawan*) \\ *) Students of Master of Notary Law, Universitas Islam Sultan Agung (UNISSULA) \\ Semarang
}

\begin{abstract}
The research objective is to unto know and analyze application Affixing the thumbprint in making land sale and purchase deeds, unto know and analyze legal consequences of affixing a thumbprint in the making of a land sale and purchase deed, and untuk know and analyze the extent of the function Affixing the thumb print in the making of the land sale and purchase deed. This research is a qualitative research with a normative juridical approach. This research was conducted in Kendal Regency. Based on the results of research and discussion it can be seen that "The application of the thumbprint affixing in making the sale and purchase deed of the tappers in minuta by the notary / PPAT is to identify the presence of the tappers. Proof of presence that the person who comes to the Notary / PPAT is the person concerned who wants to make a Notary / PPAT Deed, not someone else. The thumbprint affixing has legal consequences in the making of the Land Sale and Purchase Deed because it has benefits before the signing of the deed by the notary so that the notary still has the opportunity to correct previously unseen mistakes. One of the purposes of affixing the thumbprint before signing the deed is that It is a guarantee for the parties that the signed deed is the same as what has been read, and the deed is read so that the parties can be certain that the writing or content of the deed is true to the wishes of the tappers. The function in the application of affixing a thumbprint in making deeds is to identify the presence of tappers. Proof of presence that the person who came to the Notary / PPAT was the person concerned who wanted to make a Notary / PPAT Deed, not someone else. The obligation to attach the tappers' fingerprints to the Minuta Deed of Notary / PPAT aims to anticipate if one day the tappers deny their signature on the Minuta Deed of Notary / PPAT, then as additional evidence used the tapping's fingerprint. Suggestions were submitted for compliance and legal awareness from the community Affixing the thumbprint in the making of the land sale and purchase deedit must be improved, among others, through legal counseling, distribution of pamphlets related to land law issues in a communicative language so that it can be understood by the general public, or through other reading materials, and also through the mass media so that through various methods it is expected people who were previously blind to the law can know and understand the law. And if you already know and understand the law, then this will be able to increase the degree of compliance and legal awareness of the community in the field of land law.
\end{abstract}

Keywords: Legal Aspects; Affixing Thumbprints; Deeds of Sale and Purchase of Land. 


\section{Introduction}

Notary Public/ PPAT is a public official who is appointed by the Government to assist the general public in terms of making agreements that exist or arise in the community. Notary duties/ PPATprovide assistance on making authentic deeds. And thus, it is important for notaries to be able to understand the provisions regulated by law so that the general public who do not know or do not understand the rules of law, can understand correctly and do not do things that are contrary to the law. ${ }^{1}$

Article 16 Act No. 2 of 2014 regarding amendments to Act No. 30 of 2004 concerning the Position of Notary/ PPAT states that: In carrying out his / her position, the Notary / PPAT is obliged to c. affixing letters and documents as well as the tappers' fingerprints on the Minuta Deed;

A statutory order in taking fingerprints of the intruders in minutes by a notary public/ PPAT certainly raises various interpretations, whether the thumbprint replaces the signature, or vice versa. Is taking fingerprints of tappers in minuta by the Notary / PPAT a requirement in ratifying the agreement, then what about the terms of the agreement set out in Article 1320 of the Civil Code. This is of course a separate legal gap in the practice of its implementation.

Lawrence M. Friedman in the theory of "Legal System" states that the components of the legal system include three elements, namely:

1. The substance of the law (substance rule of the law), it covers all written and unwritten rules, both material law and formal law

2. Legal structure (structure of the law), covers legal institutions, legal apparatus and law enforcement systems. The legal structure is closely related to the judicial system implemented by law enforcement officials, in the criminal justice system, law enforcement applications are carried out by investigators, prosecutors, judges and lawyers.

3. Legal culture (legal culture), is an emphasis from the side of culture in general, habits, opinions, ways of acting and thinking, which directs social forces in society. ${ }^{2}$

This means that there are three legal sub-systems which are the determining factors in implementing a law / applying a law. Soerjono Soekanto stated that laws are written regulations that are generally accepted and made by the legal authorities at the central and regional levels. The law is the embodiment of values agreed upon by the government. The problem that often occurs is that

\footnotetext{
${ }^{1}$ Andasasmita, Komar. (1993). Notaris Selayang Pandang, Cet. 2, Bandung: Alumni. p. 2.

${ }^{2}$ Friedman, Lawrence M. (2009). The Legal System; A Social Scince Prespective, translation M. Khozim, Bandung: PT. Nusa Media. p. 12-16.
} 
the law does not yet have implementing regulations even though the law is mandated to do so, then there are laws that are not followed by the principles of enactment of the law and the ambiguity of the meaning of the words in the law which results in confusion in interpretation and application. ${ }^{3}$

Notary Public/ PPAT on the one hand has an obligation to implement Article 16 Act No. 2 of 2014 regarding amendments to Act No. 30 of 2004 concerning the Position of Notary/ PPAT, but on the other hand, if the regulation is not clear, it will be difficult to implement / apply. So the application of the principles of accuracy and prudence through taking fingerprints of the interlocutors in minutes by a notary in Kendal Regency, becomes an interesting study because besides the regulations are still new, on the other hand it is a study that has never been studied.

Based on the problems that have been formulated above, the objectives to be achieved in this study are: unto know and analyze application Affixing the thumbprint in making land sale and purchase deeds, unto know and analyze legal consequences of affixing a thumbprint in the making of a land sale and purchase deed, and untuk know and analyze the extent of the function Affixing the thumbprint in the making of the land sale and purchase deed.

\section{Research Methods}

\subsection{Approach Method}

The approach method used is normative juridical. The normative juridical approach method was chosen because it fits the research objectives, namely to examine the application of the principles of accuracy and caution through taking fingerprints of the actors in minimum by a notary / PPAT in Kendal Regency and its obstacles.

\subsection{Research Specifications}

The specification of this research is descriptive, which is a study that describes the state of the object to be studied. ${ }^{4}$ This research will describe the application of the principles of accuracy and prudence through taking fingerprints of the intruders in minutes by a notary in Kendal Regency.

\subsection{Research sites}

This research was conducted in Kendal Regency, especially the Notary Office / PPAT in Kendal Regency. In addition, to collect secondary data, the research was conducted at the Unisula Semarang Library.

\footnotetext{
3 Soekanto, Soerjono. (2011). Faktor-Faktor Yang Mempengaruhi Penegakan Hukum, Jakarta: PT.Raja Grafindo Persada. p. 17-18.

${ }^{4}$ Ibid, p. 16.
} 


\subsection{Data analysis}

This study uses a qualitative method, which describes the data in a quality manner, in the form of regular, sequential, logical, non-overlapping and effective sentences, and then a discussion is carried out. Based on the results of the discussion, conclusions were drawn in response to the problems being studied. ${ }^{5}$

\section{Results and Discussion}

\subsection{Application Affixing the thumbprint in the making of the land sale and purchase deed}

Land buying and selling institution is a legal act that is cash in nature. In buying and selling land, the most important thing is the interests of the buyer in relation to the seller. The land rights in question have been transferred to the buyer when the legal action of the sale and purchase is completed or when the sale and purchase deed is signed by the seller and the buyer in the presence of a PPAT.

The sale and purchase made before the PPAT can be carried out if all the objective and subjective requirements of both the seller and the buyer are fulfilled. The objective requirements are whether the rights to the land can be transferred, if the land is agricultural then those who can buy and receive the land are the people who meet the requirements for it. Subjective requirements, namely whether the person or legal entity is authorized to buy or have rights to the land.

Based on the description above, it can be concluded that a legal act of relinquishing rights to land is an act in which the right holder gives up his right, such as someone selling his land as a seller, then receiving compensation in the form of a sum of money such as the selling price of the land and the right recipient as the buyer.

Before a legal action is taken to relinquish the right, of course there is an agreement in the form of an agreement between the land owner and those who need it. The agreement regarding both the surrender of the land and the compensation is usually called compensation such as buying and selling, for example the price of the land.

Based on the results of an interview with a Notary in Kendal Regency, it was stated that the notary was authorized to make a deed of relinquishment of rights

${ }^{5}$ Sugiyono. (2008). Memahami Penelitian Kualitatif, Bandung: Alfabeta. p. 92. 
even if requested by a client based on Article 16 paragraph (1) letter $d$ of Act No. 2 of 2014 concerning Notary Position which reads as follows:

A notary is obliged to provide services in accordance with the provisions of this Law, unless there is a reason to refuse it.

Article 37 Government Regulation Number 24 of 1997 states that:

Transfer of land rights and ownership rights to apartment units through sale and purchase, exchange, grants, company data entry and other legal acts of transfer of rights except the transfer of rights through auction can only be registered if proven by deeds made by the authorized PPAT according to the provisions. prevailing laws and regulations.

The main duties and powers of the PPAT as stated in Article 2 paragraph (1) of the Republic of Indonesia Government Regulation Number 37 of 1998 concerning Land Deed Making Officials are to carry out part of the land registration activities by making deeds as evidence of certain legal actions regarding land rights or rights. Ownership of Apartment Units which will be used as the basis for land registration resulting from this legal act.

Based on the provisions of Article 37 of the Government Regulation, it is clear that the PPAT's authority is to make deeds as mentioned in the article, however due to certain matters the transfer of land rights must be made before a notary, for example if a limited liability company buys a plot of land with the status of Ownership.

The transfer of land rights which the deed should have been drawn up before the PPAT can also be made before a Notary Public, this can be due to several conditions that have not been fulfilled by the seller or the buyer, namely:

1. a certificate of land which is the object of sale and purchase is still bound by a guarantee of Encumbrance (APHT), which must first be processed (erased) by the APHT at the Office of the National Land Agency,

2. a certificate that is still registered in the name of another person or heir, must first be reversed on the name of the right holder or on the name of the heir,

3. the master certificate has not been broken down while only a small portion of the land has been purchased.

4. The buyer of ownership rights over the land is a limited liability company which is not justified by law to own ownership rights over the land,

5. the land to be purchased is still absentee land, ${ }^{6}$

6. Hak Milik land buyers are foreigners who are not entitled to own ownership rights over land in Indonesia except for the Use Rights,

7. the buyer already owns land that exceeds the maximum limit stipulated by law so that there must be or get permission from the competent official for that,

${ }^{6}$ Harsono, Budi. (1999). Hukum Agraria Indonesia, Jakarta : Djambatan. p. 371. 
8. income tax (PPh) based on Act No. 17 of 2000 which is the obligation of the seller has not been paid,

9. Land acquisition tax (BPHTB) based on Act No. 20 of 2000 which is the obligation of the buyer has not been paid.

10. the certificate has not been issued or is still in the process of being processed at the National Land Agency Office.

One of the public officials who has the power to make an authentic deed is a notary, this assumption is based on the provisions in Act No. 2 of 2014 concerning the Position of Notary (UUJN) Article 1 point 1 states that:

"Notary is a public official who is authorized to make authentic deeds and has other powers as referred to in this Law or based on other Laws".

An authentic deed according to article 1868 of the Civil Code is a deed made in the form determined by law by / or before a public official authorized for that purpose, at the place where the deed was made. Based on Article 1868 of the Civil Code, it can be seen that there are two forms of deeds, namely deeds made "by" a notary or so-called "deed of relaas" or "deed of officials" (ambtelijke akten) and deeds drawn "before" a notary or so-called "Deed partij" (partij akten).

The authority of a notary as a general official in making deeds in detail has been regulated in Article 15 paragraph (1) and paragraph (2) UUJN which includes general authority and special authority. As a limitation on the authority he has in Article 16 of the UUJN, the Notary is assigned several obligations. One of the obligations of a notary is to attach the applicant's fingerprint to the deed of minuta which is clearly explained in Article 16 paragraph (1) letter c of the UUJN, reads:

In carrying out his position, the Notary is obliged to: attach letters and documents as well as fingerprints of the applicant on the minimum deed.

Based on the clause of the article, it is mandatory for the tappers to have their fingerprints attached to the minuta deed. However, if you look at the meaning of the minimum deed in Article 1 point 8 UUJN. Minuta deed is the original deed which includes the signatures of the tappers, witnesses, and notaries which are kept as part of the notary protocol. It appears that there is no fingerprint of the tappers attached to the Minuta deed.

The reason for the need for a notary's obligation to attach fingerprints to the minuta deed is based on the government's proposal in the Government Draft represented by the Ministry of Law and Human Rights at the Minutes of the RUJN Draft Session which proposes provisions regarding Notary obligations in Article 16 paragraph (1) letter $c$ as regulated in UUJN new based on a wealth of government experience. 
In the application of Article 16 paragraph (1) letter $\mathrm{c}$ of this Law on the Position of Notary Public, the attachment of the face's fingerprint to the deed by the Notary can be done by using a digital fingerprint or using conventional fingerprint ink. Regarding the finger used for fingerprinting, there is no specificity for which finger the fingerprint is taken because each finger already has a mark with its respective formula. Attaching fingerprints to the minutas of deeds means affixing fingerprints on a separate sheet of paper that is attached to the minutas of deeds, which is a legal obligation that does not determine the legality or authenticity of a deed and only serves to ensure the correctness of the identity of the applicant.

The obligation to attach tappers' fingerprints on the Minuta Deed of Notary is aimed at anticipating that one day the tappers deny their signature on the Minuta Deed, then as additional evidence the tapping's fingerprints are used as additional evidence. There are benefits to affixing the tappers' fingerprint documents to the Minuta deed and is a precautionary gesture. However, if the obligation to attach the fingerprint document is obliged to the applicant who is able to sign his / her signature, this obligation should also be applied to the witnesses, because the presence of witnesses is one of the requirements for the authenticity of a notary deed.

Based on the description above, it can be seen that Affixing the thumbprint in the making of the land sale and purchase deed tapping in minuta by a notary in the Kendal Regency area is for identification of the presence of the intruder. Proof of presence that the person who comes to the Notary is the person concerned who wants to make a Notary Deed, not someone else. The obligation to attach the tappers' fingerprints to the Minuta Notary Deed aims to anticipate if one day the tappers deny their signature on the Minuta Notary Deed, then as additional evidence the tapping's fingerprints are used as additional evidence.application of the principles of accuracy and prudence through taking fingerprints of the interlocutors in minutes by notaries in the Kendal Regency area to avoid imposition Notary in accordance with Article 16 paragraph (11) of the Law on the Position of Notary Public. This sanction is a sanction against a Notary in connection with the deed made by the Notary. If the sanction of a written warning to the Notary is not obeyed or there is a violation by the Notary concerned, the next sanction may be imposed in stages.

The obligation to attach Thumbprints in the Making of the Deed of Sale and Purchase of Land for the applicant to the Minuta deed is a legal action as an additional requirement which is a manifestation of the Notary's prudence in carrying out his position as an effort to anticipate if in the future the applicant denies the signature he has put on the Minuta deed. 


\subsection{The affixing of the thumbprint has legal consequences in the making of the land sale and purchase deed}

So far, notarial deed preparation has started with the notary deed making mechanism.

1. The tappers came and appeared before the notary and conveyed the parties' intentions to make an agreement in written form and had legal force

2. After the notary listens to the aims and objectives of the parties, it will be determined whether the deed made is the deed of relaas or deed of party.

3. Notaries make deeds in accordance with Article 38 of Law of the Republic of Indonesia Number 2 of 2014 concerning Amendments to Act No. 30 of 2004 concerning Notary Position.

4. After the deed has been drawn up, it ends with reading and signing the deed in front of witnesses by the parties as well as witnesses. The deed is read by a notary with the intention of:

a. Guarantee to the parties that what is signed is the same as what was heard during the reading of the deed. ${ }^{7}$

b. Assurance for the parties that what is written in the deed is true of the wishes of the parties and has been approved by each party.

Reading the deed is not only beneficial for the notary but also beneficial for tappers, here are some of the benefits of affixing a thumbprint before signing the deed by a notary:

a. Notaries still have the opportunity to correct previously unseen mistakes. Reading the deed is the last possibility for a notary to check the deed that has been made, but this benefit is not the only one.

b. Interviewers have the opportunity to ask questions about things that are not clear in the contents of the deed

c. The thumbprint affixing before the signing of the deed comes an opportunity for the notary and the tappers at the last second, before the deed is formalized with the signature of the parties, witnesses and notaries to rethink in other words revision of the contents of the agreement so that problems do not arise in the future.

Notary deed, hereinafter referred to as deed, is an authentic deed made by or before a Notary according to the form and procedure stipulated in this law as stated in Article 1 point 7 of the Law on the Position of Notary Public. There are 2 types of notary deeds, namely deeds made by Notaries, which are commonly referred to as Deeds of Relaas or minutes and deeds made before Notaries, commonly referred to as Deed of Parties or Deed of Partij. An authentic deed which in the making is affixed with a signature at the end of the deed results in the deed becoming valid in the eyes of the law and can be used as perfect

\footnotetext{
${ }^{7}$ Articles 40-44, Law of the Republic of Indonesia Number 2 of 2014 concerning Amendments to Act No. 30 of 2004 concerning the Position of Notary.
} 
evidence, as long as in the process of making it has fulfilled the provisions of Article 1320 of the Civil Code as a condition of validity of the agreement, Article 1868 of the Civil Code and Act No. 30 of 2004 concerning the Position of Notary in conjunction with Act No. 2 of 2014 concerning Amendments to Act No. 30 of 2004 concerning the Position of Notary Public. The form of the authentic deed is regulated in Article 38 of the Law on the Position of Notary Public. In this article, it is quite clear that the form and nature of the authentic deed made by a notary is quite clear.

Deeds made by Notaries are authentic deeds drawn up according to law, drawn up in the presence of authorized public officials. This is as stated in Article 1868 BW. In making authentic deeds as perfect evidence, in addition to fulfilling the provisions of Article 1868 BW, they must also comply with the provisions and procedures of the statutory regulations, namely Act No. 2 of 2014 concerning amendments to Act No. 30 of 2004 concerning the Position of Notary Public.

The affixing of thumbprints has legal consequences. In the making of the Deed of Sale and Purchase of Land according to Act No. 2 of 2014 concerning Amendments to Law Number 30 of 2004 concerning the Position of Notary Public, the deed made is an authentic deed. This is in accordance with the provisions of Article 1 paragraph 1 of Act No. 30 of 2004, Notary is a public official who has the authority to make authentic deeds and other powers as referred to in the Law. In Article 1 paragraph 7, it is stated that, Notary deed is an authentic deed made by or before a Notary according to the form and procedure stipulated in this Law. The making of authentic deeds is required by statutory regulations in order to create legal certainty, order and protection.

The authentic deed basically contains the formal truth in accordance with what the parties have notified to the Notary. The notary public has the obligation to include that what is contained in the notary deed has actually been understood and is in accordance with the wishes of the parties, namely by reading it so that the contents of the notary deed become clear, as well as providing access to information, including access to the relevant laws and regulations for the parties signing the deed, thus the parties can freely determine and agree on the contents of the notary deed to be signed.

Through an authentic deed that clearly defines rights and obligations, guarantees legal certainty, and at the same time it is hoped that disputes can be avoided. In the dispute resolution process, the authentic deed which is the strongest and most fulfilled written evidence gives a real contribution to the settlement of cases cheaply and quickly. In a juridical sense, proof is only needed in a case before the Court, be it a civil or criminal case, thus, if there is no dispute, the proof is not necessary. 
Thumbprint stamp affixing the deed is carried out at the notary's office, so to protect the legal actions of the bank and also the notary itself in terms of signing the deed before a notary, which must be supported by adequate facilities such as voice recorders, CCTV, and photos. . Thus, which is also to avoid potential disputes in the future.

\subsection{Function in Application Affixing the thumbprint in the making of the land sale and purchase deed}

Article 1 number 1 of Act No. 2 of 2014 concerning Amendments to Act No. 30 of 2004 concerning the Position of Notary (here in after referred to as the Law on the Position of Notary) states that: "Notaries are public officials who are authorized to make authentic deeds and have the authority others as referred to in this law or based on other laws

In the explanation of the Law on the Position of Notary Public, it is explained that:

"The authentic deed essentially contains the formal truth in accordance with what the parties have notarized to the notary. However, the Notary Public has the obligation to include that what is contained in the Notary deed has been understood and is in accordance with the wishes of the parties, namely by reading it so that the contents of the Notary deed are clear, as well as providing access to information, including access to laws and regulations for the parties signing the deed. Thus, the parties can freely determine whether to approve or not to approve the contents of the Notary deed they have signed. "

In the Law of Notary, various rules are made which aim to: ${ }^{8}$

"First, to defend the honor and professional dignity of its members who take actions that can undermine that honor and dignity. Second, protecting people who use the services of the profession so that they are prevented from services that do not meet certain standards or malpractices. Third, separating individuals who carry out their professions properly and correctly from individuals who carry out a modest profession, can even lower the dignity of the profession in general".

The Law on the Position of Notary Public regulates in detail the general positions held by a Notary, so that an authentic deed "made by" or "made before" a Notary is able to guarantee legal certainty, public order and legal protection.

We can see the need for law in society with the increasing number of forms of agreements that are poured out by the parties in a notary deed. An agreement is a legal act that has legal consequences. "An agreement can be interpreted as an

${ }^{8}$ Gunawan, Gunardi \& Markus. (2007). Kitab Undang-Undang Hukum Kenotariatan, Jakarta: Raja Gravindo Persada. p.11. 
act to obtain a set of rights and obligations and has legal consequences which are the consequences of violating these rights and obligations".

Notary is an extension of the government, in this case the state, where the state has given trust to the Notary to carry out some state affairs, especially in the field of civil law. The existence of a Notary is expected to answer the community's need for neutral legal aid, thus protecting the legal interests of the community. Notaries are also expected to provide legal services to the community, especially in making deeds, so that people will get legal certainty and legal protection, in connection with the increasing development process so that legal needs in society also increase.

Fingerprints are the results of reproduction of the treads either deliberately taken, stamped with ink or marks left on objects because they have been touched by the skin on the palms of the hands or feet. The palm skin is the skin on the palms of the hands starting from the base of the wrists to all the tips of the fingers, and the skin on the soles of the feet starting from the heels to the tips of the fingers where in that area there are fine lines protruding from each other separated by gaps or grooves which forms a particular structure.

From this understanding and also from the writings that the authors read, both related to fingerprints, according to the author, the word "fingerprint" can mean the footprint of one of the fingers on the hand or foot or it can also mean the entire tread of the fingers or fingers. toes or tread of the skin of the right and / or left hand, or the tread of the palm from the base of the wrist to all the tips of the fingers and / or the tread of the skin of the sole of the foot starting from the heel $\mathrm{sa}$, the pie to the tip of the finger. So it can be singular or plural.

In general taking fingerprints of tappers in minuta by a notary in Kendal Regency taken for certain purposes taken using wet ink which is then stamped on certain paper / media and taken in certain ways so that the grooves contained in the fingerprint are easily visible / legible.

The background that the fingerprint of the tappers is attached to the Minuta deed is to identify the presence of the tappers. Proof of presence that the person who came to the Notary was the person concerned who wanted to make a Notary Deed, not someone else. The obligation to attach the tappers' fingerprints to the Minuta Notary Deed aims to anticipate if one day the tappers deny their signature on the Minuta Notary Deed, then as additional evidence the tapping's fingerprints are used as additional evidence. Legal implications for Notaries who do not attach their fingerprints to the Minuta Deed may be subject to sanctions in accordance with Article 16 paragraph (11) of the Law on Notary Position. This sanction is a sanction against a Notary in connection with the deed made by the Notary. 
If then we see the purpose of Article 44 Paragraph (1) UUJN above that UUJN requires that in any condition the process of signing and affixing fingerprints must be described by a notary at the end of the deed / cover of the deed, but there are still those who are unable to put their fingerprints is in the Minuta Deed, then it becomes the obligation for the Notary concerned to explain the matter in the Minuta Deed he makes.

\section{Closing}

\subsection{Conclusion}

Based on the results of research and discussion, it can be concluded as follows:

1. Application of Thumbprint Affixing in Making Land Sale and Purchase Deeds. The application of the thumbprint affixing in making the sale and purchase deed of the tappers in minuta by the notary / PPAT is to identify the presence of the tappers. Proof of presence that the person who comes to the Notary / PPAT is the person concerned who wants to make a Notary / PPAT Deed, not someone else. The obligation to attach the tappers' fingerprints to the Minuta Notary Deed aims to anticipate if one day the tappers deny their signature on the Minuta Notary Deed, then as additional evidence the tapping's fingerprints are used as additional evidence application of the principles of accuracy and prudence through taking fingerprints of the interlocutors in minutes by a notary in Kendal Regency to avoid the imposition of a Notary in accordance with Article 16 paragraph (11) of the Law on the Position of Notary Public. This sanction is a sanction against a Notary in connection with the deed made by the Notary. If the sanction of a written warning to the Notary is not obeyed or there is a violation by the Notary concerned, the next sanction may be imposed in stages.

2. The affixing of the thumbprint has legal consequences in the making of the land sale and purchase deed. Benefits of thumbprint affixing Thumbprint before signing the deed by a notary public so that the notary still has the opportunity to correct previously unseen mistakes. Reading the deed is the last possibility for a notary to check the deed that has been made, and the parties have the opportunity to ask questions about things that are unclear in the contents of the deed. The purpose of affixing a thumbprint. One of the thumbprints before the signing of the deed is to provide assurance to the parties that the signed deed is the same as what has been read, and the reading of the deed is carried out so that the parties get certainty that the writing or content of the deed is correct the will of the viewer.

3. To what extent is the function of the application of thumbprint affixing in making land sale and purchase deeds. Functions in the Application of Thumbprint Affixing Thumbprints in the Making of the Deed of Sale and Purchase of Land, namely the legal factors themselves (legislation), law enforcement factors, supporting facilities or facilities factors, community factors, cultural factors. The legal factor itself (legislation), there are often misinterpretations in the field. Regarding the application of fingerprints, we do not find this explanation in the Law and it only states "Self-explanatory", meaning that the provisions for affixing fingerprints are clear. The law enforcement factor, the Notary states that in carrying out his / her position the 
Notary is obliged to attach letters and documents as well as fingerprints of the faces to the Minuta Deed, based on the provisions of the article above, the Notary's obligation to affix the fingerprint of the face becomes unclear because there is no further explanation in Article 16 Paragraph (1) letter $c$ of the Law on Notary Position. Public factors, public legal awareness is still low, this is due to knowledge of Legal regulations, knowledge of the content and purpose contained in a certain legal regulation, legal acceptance is not yet willing to comply with them. The legal behavior pattern of society is not in accordance with legal regulations. acceptance of the law is not yet willing to comply. The legal behavior pattern of society is not in accordance with legal regulations. acceptance of the law is not yet willing to comply. The legal behavior pattern of society is not in accordance with legal regulations.

\subsection{Suggestion}

The public in general is aware of the existence and function of a notary in making authentic deeds, so to make a deed of transfer of rights to land where one of the legal subjects is not authorized to obtain a land right must be made in the presence of a notary public. Compliance and legal awareness from the community Affixing Thumbprint. It in Making Land Sale and Purchase Deeds It must be improved, among others, through legal counseling, distribution of pamphlets related to land law issues in a communicative language so that it can be understood by the general public, or through other reading materials, and also through the mass media so that through various methods it is expected people who were previously blind to the law can know and understand the law. And if you already know and understand the law, then this will be able to increase the degree of compliance and legal awareness of the community in the field of land law.

\section{References}

[1] Adrian Sutedi. (2007). Peralihan Hak Atas Tanah dan Pendaftarannya. Jakarta: Sinar Grafika.

[2] Amiruddin. (2006). Pengantar Metode Penelitian Hukum. Jakarta: PT. Raja Grafindo Persada.

[3] A.P.Parlindungan. (1991). Pedoman Pelaksanaan Undang-Undang Pokok Agraria dan Tata Cara Pejabat Pembuat Akta Tanah. Bandung: CV. Mandar Maju.

[4] _. (1999). Pendaftaran Tanah Indonesia (Berdasarkan P.P. No. 24 Tahun 1997 Dilengkapi dengan Peraturan Jabatan Pejabat Pembuat Akta Tanah (P.P. No.37 Tahun 1998). Bandung: CV. Mandar Maju.

[5] Bachtiar Efendi. (1993). Kumpulan Tulisan Tentang Hukum Tanah. Bandung: Alumni.

[6] Boedi Harsono. (2002). Hukum Agraria di Indonesia: Himpunan PeraturanPeraturan Hukum Tanah. Jakarta: Djambatan.

[7] __ (2003). Sejarah Pembentukan Undang-Undang Pokok Agraria: Isi dan Pelaksanaan. Jakarta: Djambatan. 
[8] Effendi Perangin. (1990). Praktek Jual Beli Tanah. Jakarta: Rajawali.

[9] Harahap M. Yahya. (1986), Segi-segi Hukum Perjanjian, Bandung : Alumni.

[10]Harsono, Boedi. (2002). Hukum Agraria Indonesia, Himpunan PeraturanPeraturan Hukum Tanah, (Jakarta: Djambatan).

[11]Fuadi, Munir. (1998). Hukum Kontrak Dari Sudut Pandang Hukum Bisnis, Bandung: Citra Aditya Bakti.

[12]Muhamad, Abdulkadir. (1990). Hukum Perikatan, Bandung: Citra Aditya Bakti.

[13]Perangin, Effendi. (1994). Hukum Agraria di Indonesia, Suatu Telaah dari Sudut Pandang Praktisi Hukum, Jakarta: PT.Raja Grafindo Persada.

[14]Prodikoro, Wirjono. (1986). Asas-asas Hukum Perjanjian, Bandung: Sumur Bandung.

[15]Salim H.S. (2010). Hukum Kontrak, Jakarta: Sinar Grafika.

[16]Saleh. K.Wantjik. (1997). Hak Anda Atas Tanah, Jakarta: Ghalia Indonesia.

[17]Soimin, Sudaryo. (1994). Status Tanah Dan Pembebasan Tanah, Jakarta: Sinar Grafika.

[18]Santoso, Djohari. (1995). Hukum Perjanjian Indonesia, Yogyakarta: Perpustakaan Fakultas Hukum UI, 1995.

[19]Satrio. (2001). Hukum Perikatan Yang Lahir Dari Perjanjian, Bandung: PT. Citra Aditya Bakti.

[20]Satrio. (1996). Hukum Perjanjian, Bandung: PT.Citra Aditya Bakti.

[21]----.. (1993). Hukum Perikatan, Bandung: Alumni.

[22]Soekanto, Soerjono. (2002). Kesadaran Hukum dan Kepatuhan Hukum, Jakarta: CV. Rajawali.

[23]Setiawan, R. (1987). Pokok-Pokok Hukum Perikatan, Bandung: Binacipta.

[24]Soemitro, Rony Hamitjio. (2000). Metode Penelitian Jurimetri, (Ghalia Indonesia).

[25]Subekti. (2005). Pokok-pokok hukum perdata, Jakarta: Intermasa.

[26]-------. (1995). Aneka Perjanjian, Bandung : PT. Citra Aditya Bakti.

Regulation:

[1] Code of Civil law

[2] Civil Procedure Reglemen (Rv)

[3] Act No. 5 of 1960 concerning Basic Agrarian Principles (UUPA)

[4] Government Regulation Number 24 of 1997 concerning Land Registration

[5] Presidential Regulation Number 10 of 2006 concerning the National Land Agency

[6] Regulation of the State Minister for Agrarian Affairs / Head of the National Land Agency Number 3 of 1997 concerning Provisions for the Implementation of Government Regulation Number 24 of 1997 concerning Land Registration 